\title{
Blood profile and gut microbial load of broilers fed siam weed (Chromolaena odorata) leaf meal in their diets
}

\author{
Peter-Damian Chukwunomso JIWUBA ${ }^{1}$, Ifeanyi Princewill OGBUEWU ${ }^{2}$, Elisha DAUDA ${ }^{1}$ \\ and Caritas Chibuike AZUBUIKE ${ }^{1}$ \\ ${ }^{1}$ Department of Animal Health and Production Technology, Federal College of Agriculture, \\ P.M.B.7008, Ishiagu, Ebonyi State, Nigeria. \\ ${ }^{2}$ Department of Animal Science and Technology, Federal University of Technology, P.M.B. 1526, Owerri, Nigeria.
}

\begin{abstract}
The responses of 96 day old broilers fed Chromolaena odorata leaf meal (COLM) on blood profile and gut microbial load were studied for 49 days. The birds were randomly assigned to four treatment groups and replicated three times in a completely randomized design. The birds were fed four experimental diets formulated at $0 \%, 2 \%, 4 \%$ and $6 \%$ for the starter phase and $0 \%, 4 \%, 8 \%$ and $12 \%$ of COLM at the finisher phase for T1, T2, T3 and T4 respectively. All the haematological parameters were similar $(\mathrm{P}>0.05)$ across the treatment groups except $\mathrm{MCH}$ and $\mathrm{WBC}$ which were significantly $(\mathrm{P}<0.05)$ higher and better in the treatment groups than the control group. The results on serum chemistry showed significant $(\mathrm{P}<0.05)$ difference for total protein, albumin, creatinine and cholesterol across the treatment groups. Cholesterol was significantly $(\mathrm{P}<0.05)$ reduced with increasing levels of COLM. Results showed that coliforms and E.coli were consistently higher $(\mathrm{P}<0.05)$ among the T1 birds than those fed T2, T3 and T4. It was concluded that, COLM enhanced adequate haematocrit and immune status, hypoglycaemic ability, suppresses the growth of gut pathogenic microorganisms and enhanced the growth of beneficial microorganism in broilers.
\end{abstract}

Key words: broilers, COLM, leaf meal, gut health, blood profile, medicinal plant

\section{INTRODUCTION}

Broiler production is one of the most important sources of animal protein all over the world today. This could be attributed to the high rate of feed utilization efficiency and fast growth rate of the birds (Jiwuba et al. 2016a). Poultry production has been challenged by poor physiological functions, microbial infections and unavailability of good quality feeds on a sustainable basis at stable prices. The escalating cost of conventional feedstuff has stimulated research into alternative feedstuffs with the aim of reducing the cost of poultry production, maintaining the feed quality, increasing the production rate and improving the health status of the birds.

Several alternative feedstuffs have been successively used as possible replacement either partially or wholly of conventional feedstuff. However, the alternative feed of interest in this study is the Siam weed (Chromolaena odorata). C. odorata belongs to the family Asteraceae and known by diverse names such as "Obiarakara", "Awolowo", "Diochie", "Independence", "ewe Akintola" triffid weed and bitter bush in most parts of Nigeria. It is an important perennial Tropical "obnoxious weed" because of its ability to spread to new lands within a short period of time. Earlier reports (Akinmoladun et al. 2007, Igboh 2009, Ikewuchi and Ikewuchi 2011) on C. odorata have noted its multipurpose medicinal properties. Dried leaves of C. odorata have also been reported (Moses et al. 2010) to be used as mosquito repellant, antimicrobial agent against Bacillus cereus and antifungal agent against Aspergillus

${ }^{*}$ Correspondence to:

E-mail: jiwubapc@gmail.com 
niger. The juice from the fresh leaves when applied to cuts or wounds may help reduce bleeding considerably. Other traditional medicinal uses include anti-diarrheal, astringent, antispasmodic, antihypertensive, anti-inflammatory, diuretic tonic, antipyretic and heart tonic (Vital and Windell 2009). The offensive odour of the fresh leaves could be given off when the plant is disturbed by mere touching or bruising of the leaves and this odour is greatly reduced when the leaves are sun dried for subsequent milling (Fasuyi et al. 2005). Not much has also been written on the biochemical, haematological and gut microbial population implications of siam weed leaf meal on poultry diets.

Sajise et al. (1974) reported that the importance of $C$. odorata as a cause of poisoning and death in livestock is due to its conversion either in the foodstuff or within the alimentary canal into nitrite. Nitrite converts haemoglobin of the blood to methaemoglobin which is unable to act as an oxygen carrier and this might possibly lead to the death of the animals through tissue anoxia (Fasuyi et al. 2005). Another biochemical implication with the utilization of $C$. odorata leaf may be specifically when used in combination with cassava by-products, is the affinity which methaemoglobin has for cyanide leading to the formation of cyanmethaemoglobin which is another oxygen depleting compound in the blood (Fasuyi et al. 2005). Although nutritive research on C. odorata leaves and its use in broiler diets remain scanty, it has been however reported to be relatively high in crude protein, dry matter, vitamins and minerals (Apori et al. 2000). This study was therefore designed to determine the serum biochemical, haematological profile and gut microbial population of broilers fed C. odorata leaf meal in their diets.

\section{MATERIALS AND METHODS}

\section{Experimental Site}

The experiment was carried out at the poultry Unit of Federal College of Agriculture, Ishiagu, Ivo Local Government Area, Ebonyi state, Nigeria. The College is located at about three kilometres $(3 \mathrm{~km})$ away from Ishiagu main town.

Processing of COLM. The fresh leaves of green succulent unflowered Chromolaena odorata were harvested with the College environment. The leaves were later sundried for five days to obtain about $10 \%$ moisture. They were thereafter milled by passing through $1 \mathrm{~mm}$ hammer mill, before been used to formulate the experimental diets.

Experimental Diets: Four experimental diets designated as $\mathrm{T} 1, \mathrm{~T} 2, \mathrm{~T} 3$, and $\mathrm{T} 4$ where formulated to contain $0,2,4,6$, levels of COLM at starter phase and $0,4,8,12$, levels at finisher phase. The compositions of the experimental diets are given in Table 1 and Table 2.

Experimental Animals, Housing and Management: Ninety six (96) day old Abor acre chicks were sourced from a Chi farms in Ibadan, Oyo state, Nigeria. They were randomly assigned to four (4) experimental treatment groups, each replicated three (3) times with eight (8) birds constituting a replicate. The birds were assigned the four experimental diets in a Completely Randomized Design (CRD) and fed the experimental diets for 49 days. Each replicate was housed in
Table 1: Percentage composition of the experimental diets for starter birds.

\begin{tabular}{|l|c|c|c|c|}
\hline Ingredients & T1 & T2 & T3 & T4 \\
\hline Maize & 52.00 & 52.00 & 51.00 & 51.00 \\
\hline Wheat offal & 7.00 & 6.00 & 5.00 & 3.00 \\
\hline Soybean meal & 35.00 & 34.00 & 34.00 & 32.00 \\
\hline $\begin{array}{l}\text { Chromolaena } \\
\text { odorata leaf } \\
\text { meal }\end{array}$ & 0.00 & 2.00 & 4.00 & 6.00 \\
\hline Fish meal & 2.00 & 2.00 & 2.00 & 2.00 \\
\hline Bone meal & 2.50 & 2.50 & 2.50 & 2.50 \\
\hline Limestone & 0.50 & 0.50 & 0.50 & 0.50 \\
\hline $\begin{array}{l}\text { Vitamin } \\
\text { premix }\end{array}$ & 0.25 & 0.25 & 0.25 & 0.25 \\
\hline Salt & 0.25 & 0.25 & 0.25 & 0.25 \\
\hline Lysine & 0.25 & 0.25 & 0.25 & 0.25 \\
\hline Methionine & 0.25 & 0.25 & 0.25 & 0.25 \\
\hline TOTAL & $\mathbf{1 0 0}$ & $\mathbf{1 0 0}$ & $\mathbf{1 0 0}$ & $\mathbf{1 0 0}$ \\
\hline $\begin{array}{l}\text { Calculated } \\
\text { values }\end{array}$ & 22.91 & 22.66 & 22.4 & 22.4 \\
\hline $\begin{array}{l}\text { Crude protein } \\
\%\end{array}$ & 2907.22 & 2902.8 & 2898.45 & 2891.31 \\
\hline $\begin{array}{l}\text { Metabolisable } \\
\text { energy kcal/ } \\
\text { kg) }\end{array}$ & & & & \\
\hline
\end{tabular}

Table 2: Percentage composition of the experimental diets for finisher birds.

\begin{tabular}{|l|c|c|c|c|}
\hline Ingredients & T1 & T2 & T3 & T4 \\
\hline Maize & 55.00 & 53.00 & 51.00 & 55.00 \\
\hline Wheat offal & 10.00 & 9.00 & 8.00 & 3.00 \\
\hline $\begin{array}{l}\text { Soya bean } \\
\text { meal }\end{array}$ & 28.55 & 27.55 & 26.55 & 23.55 \\
\hline $\begin{array}{l}\text { Chromolaena } \\
\text { odorata leaf } \\
\text { meal }\end{array}$ & 0.00 & 4.00 & 8.00 & 12.00 \\
\hline Fish meal & 2.00 & 2.00 & 2.00 & 2.00 \\
\hline Bone meal & 2.00 & 2.00 & 2.00 & 2.00 \\
\hline Limestone & 1.00 & 1.00 & 1.00 & 1.00 \\
\hline $\begin{array}{l}\text { Vitamin } \\
\text { premix }\end{array}$ & 0.35 & 0.35 & 0.35 & 0.35 \\
\hline Salt & 0.25 & 0.25 & 0.25 & 0.25 \\
\hline Lysine & 0.35 & 0.35 & 0.35 & 0.35 \\
\hline Methionine & 0.50 & 0.50 & 0.50 & 0.50 \\
\hline TOTAL & $\mathbf{1 0 0}$ & $\mathbf{1 0 0}$ & $\mathbf{1 0 0}$ & $\mathbf{1 0 0}$ \\
\hline $\begin{array}{l}\text { Calculated } \\
\text { values }\end{array}$ & & & 2901.30 \\
\hline $\begin{array}{l}\text { Crude protein } \\
\text { \% }\end{array}$ & 20.87 & 20.02 & 20.23 & 19.6 \\
\hline $\begin{array}{l}\text { Metabolisable } \\
\text { energy kcal/ } \\
\text { kg) }\end{array}$ & 2931.68 & 2920.18 & 2911.65 & 2901 \\
\hline
\end{tabular}


a concrete floor covered with wood shavings as litter material. Before the arrival of the day old chicks, the brooding house was washed and disinfected and allowed to dry. The brooder house was pre-heated for 6-12hrs to enable it reach the normal temperature $\left(32^{\circ} \mathrm{C}\right)$ required by day old chicks. Fresh feed and water was provided ad libitum. Heat and light was provided for the first 14 days using stoves and electric bulbs. The birds were vaccinated against infectious bursal (Gumboro) disease at days 10 and 24 respectively, while the NDV - Lasota vaccine was given on day 1, 14 and 28 to protect against New Castle Disease.

Blood profile analysis: Blood samples $(5 \mathrm{ml})$ were drawn from one bird per replicate on the last day of the study. The birds were bled through the marginal wing vein. The samples were separated into two lots and used for biochemical and haematological studies. An initial $2.5 \mathrm{ml}$ was collected from each sample in labelled sterile universal bottle containing 1.0 $\mathrm{mg} / \mathrm{ml}$ ethyldiamine tetracetic acid and used for haematological analysis. Another $2.5 \mathrm{ml}$ was collected over anti-coagulant free bottle. The blood was allowed to clot at room temperature and serum separated by centrifuging within three hours of collection. Serum biochemistry and haematological parameters were measured using Beckman Coulter Ac-T10 Laboratory Haematology Blood Analyzer and Bayer DCA $2000+\mathrm{HbA} 1 \mathrm{c}$ analyzer, respectively. Mean cells haemoglobin $(\mathrm{MCH})$, mean cell volume (MCV) and mean cell haemoglobin concentrations (MCHC) were calculated.

Microbial analysis: From the eviscerated organs i.e (1 birds/replicate), a section of the caecum and crop were cut and used for microbial analysis. Approximately $1 \mathrm{~g}$ of the caecal and crop content wastes mixed with $9 \mathrm{ml}$ of pre-reduced sterile dilution blank solution (Bryant and Burkey 1953), and homogenized for 3 minutes individually. From the initial $10^{1}$ dilution, 6 -fold serial dilutions were made in sterile pre-reduced dilution blank solution for total coliforms, lactic acid bacteria (LAB's) and total microbes. For each dilution, $1 \mathrm{ml}$ was inoculated in medium which include MRS agar for LAB's, MacConkay agar for coliforms and Nutrient agar for total microbes. The serially diluted samples were inoculated into growth media for coliform, Lactobacillus and Escherichia coli. Coliform bacteria were enumerated on McConkey agar (Merck kgaa b4271). Escherichia coli were enumerated on fluorescent (VRB agar Merck Kgaa) while Lactobacillus was enumerated on M. R.S. (de Man Rogosa and Sharp) agar. All the inoculated plates were then incubated at $37-40^{\circ} \mathrm{C}$ between 24-48 hours. Total number of bacterial colonies was counted at the end of each incubation period using improved bacteria colony counter (Jin et al. 1998).

Chemical Analysis: Chemical analysis (dry matter, crude protein, crude fibre, ash, and ether extract) of different experimental diets and that of the test ingredient was carried out at the College of Animal Science and Animal Production, Michael Okpara University of Agriculture, Umudike, Animal Nutrition Laboratory, using the methods of (AOAC 2000). The nitrogen free extract was derived by subtracting the sum of other components (crude protein, ether extract, ash, crude fibre) from 100 on dry matter basis.

Statistical Analysis: The results were analyzed using the SPSS Window 17.0. One - way analysis of variance ANOVA) was employed to determine the means and standard error. Differences between treatments means was estimated by Duncan Multiple Range Test.

\section{RESULTS}

\section{Chemical analysis}

The chemical composition of the experimental diets and Chromolaena odorata leaf meal are presented in Table 3. The experimental diets and COLM were analyzed for dry matter (DM), crude protein (CP), crude fibre (CF), ash, ether extract (EE) and nitrogen free extract (NFE). The DM contents of the experimental diets (starter and finisher diets) failed to follow a regular trend. The DM for the starter diets ranged between 90.71 and $92.75 \%$ while that of the finisher diets varied from $92.71-94.40 \%$. The CP content of the starter diets decreased with increased levels of COLM with the highest value $(22.36 \%)$ recorded for T1 with a corresponding lowest value of $20.52 \%$ recorded for T4. However, the CP for the finisher diets ranged between 19.38 and $19.68 \%$. The CF of the starter diets maintained a particular trend, decreasing with an increasing level of COLM till T3. The value for T4 is numerically higher for T2 and T3 diets. The CF of the finisher diets ranged from 4.00-4.94\%, and did not follow a specific trend. The ash values for the starter diets ranged between 12.53 and $13.30 \%$ while that of the finisher diets ranged from $15.84-19.19 \%$ and all did not follow a specific trend across the treatment groups. The EE content for the starter diets ranged between 2.15 and $5.00 \%$ while that of the finisher diets ranged from $2.45-5.45 \%$ and all failed to follow a specific trend across the treatments. The NFE contents of

Table 3: Chemical compositions of diets.

\begin{tabular}{|l|c|c|c|c|c|c|c|c|c|}
\hline & \multicolumn{4}{|c|}{ Starter diets } & \multicolumn{4}{c|}{ Finisher diets } & T3 \\
\hline Parameter & T1 & T2 & T3 & T4 & T1 & T2 & T3 & COLM \\
\hline Dry matter & 90.71 & 92.30 & 91.26 & 92.75 & 94.40 & 93.46 & 92.71 & 94.15 & 95.70 \\
\hline CP & 22.36 & 21.68 & 20.95 & 20.52 & 19.38 & 19.68 & 19.68 & 19.68 & 20.52 \\
\hline Crude fibre & 3.63 & 3.04 & 3.30 & 3.54 & 4.30 & 4.00 & 4.94 & 4.00 & 5.58 \\
\hline Ash & 12.60 & 12.53 & 13.30 & 12.69 & 15.84 & 18.70 & 19.19 & 19.03 & 9.29 \\
\hline Ether extract & 2.15 & 3.85 & 5.00 & 4.50 & 5.25 & 5.45 & 2.45 & 3.85 & 6.10 \\
\hline NFE & 46.97 & 49.20 & 47.71 & 50.04 & 49.63 & 45.79 & 49.45 & 48.59 & 53.94 \\
\hline
\end{tabular}

$\mathrm{CP}=$ Crude protein NFE $=$ Nitrogen free extract COLM $=$ Chromolaena odorata leaf meal 
Table 4: Haematology of broiler birds fed Chromolaena odorata leaf meal in their diets.

\begin{tabular}{|c|c|c|c|c|c|}
\hline parameter & $\mathrm{T} 1$ & $\mathrm{~T} 2$ & T3 & T4 & SEM \\
\hline Packed Cell Volume (\%) & 38.97 & 44.57 & 33.10 & 41.20 & 1.45 \\
\hline Red Blood Cell (X1012/l) & 2.98 & 3.22 & 2.95 & 2.94 & 0.23 \\
\hline Haemoglobin $(\mathrm{g} / \mathrm{dl})$ & 11.30 & 12.77 & 11.93 & 11.57 & 0.40 \\
\hline $\mathrm{MCHC}(\%)$ & 28.33 & 28.00 & 28.17 & 27.87 & 0.49 \\
\hline $\mathrm{MCH}(\mathrm{pg})$ & $26.13^{\mathrm{b}}$ & $29.53^{\mathrm{a}}$ & $27.70^{\mathrm{ab}}$ & $26.87^{\mathrm{b}}$ & 0.51 \\
\hline Mean Corpuscular Volume (f) & 90.03 & 91.47 & 93.41 & 96.74 & 1.90 \\
\hline White Blood (Cell X10 $\left.{ }^{12 / 1}\right)$ & $11.24^{\mathrm{b}}$ & $16.80^{\mathrm{a}}$ & $18.84^{\mathrm{a}}$ & $19.35^{\mathrm{a}}$ & 0.45 \\
\hline
\end{tabular}

${ }^{\mathrm{a}, \mathrm{b}}$ Means within the same row with different superscripts are significantly different $\mathrm{P}<0.05$

$\mathrm{MCHC}=$ Mean corpuscular heamoglobin concentration: $\mathrm{MCH}=$ Mean corpuscular haemoglobin

the experimental diets (starter and finisher diets) also did not follow a regular trend and ranged from $46.97-50.04 \%$ and 45.79-49.63\% for starter and finisher diets respectively. The COLM showed a high DM value of $95.70 \%$ with a higher CP value of $20.52 \%$ for leaf meals. It also showed a low CF value of $5.5 \%$ with a corresponding high ash content of $9.29 \%$. NFE and $\mathrm{EE}$ content of 53.94 and $6.10 \%$ respectively were also recorded for the COLM.

\section{Haematological analysis}

The haematological parameters of broiler birds fed Chromolaena odorata leaf meal in their diets are presented in Table 4. The packed cell volume (PCV) did not follow a particular trend, but was numerically higher in T2, T4, T1 and T3 in that order. The PCV values were not significantly $(\mathrm{P}>0.05)$ affected across the treatment groups. The red blood cell, haemoglobin, mean corpuscular haemoglobin concentration (MCHC), and mean corpuscular volume (MCV) values also followed the same trend as PCV showing no significant difference $(\mathrm{P}>0.05)$ across the treatments. The mean corpuscular haemoglobin $(\mathrm{MCH})$ was significantly $(\mathrm{P}<0.05)$ influenced. However, $\mathrm{T} 1$ was not significantly $(\mathrm{P}>0.05)$ different from $\mathrm{T} 3$ and $\mathrm{T} 4$, but was significantly $(\mathrm{P}<0.05)$ different from $\mathrm{T} 2$. The white blood cell $(\mathrm{WBC})$ was also significantly $(\mathrm{P}<0.05)$ influenced by COLM in the diets of the broilers. The WBC values followed a particular trend, increasing with increasing levels of COLM in the diets. T1 was significantly $(\mathrm{P}<0.05)$ lower than $\mathrm{T} 2, \mathrm{~T} 3$ and $\mathrm{T} 4$.

\section{Serum chemistry}

The blood chemistry of broilers fed Chromolaena odorata leaf meal in their diets is presented in Table 5. The total protein was significantly $(\mathrm{P}<0.05)$ higher for the treatment groups (T2, T3 and T4) in comparison with the control group (T1). The albumen showed $(\mathrm{P}>0.05)$ similarities between $\mathrm{T} 1$ and T2 while T3 and T4 was significantly $(\mathrm{P}<0.05)$ different from $\mathrm{T} 1$. The globulin had a progressive increase across the treatments with incremental levels of COLM in the diets. Globulin also showed $(\mathrm{P}>0.05)$ similarities between $\mathrm{T} 1$ and T2 while T3 and T4 was significantly $(\mathrm{P}<0.05)$ different from T1. Urea, aspartate amino transferase (AST), and amino transferase (ALT) showed no significant $(\mathrm{P}>0.05)$ difference across the treatments and also failed to follow a particular pattern with increasing or decreasing levels of COLM. The creatinine showed significant $(\mathrm{P}<0.05)$ with $\mathrm{T} 1, \mathrm{~T} 2$ and $\mathrm{T} 3$ showing no significant difference among each other, while $\mathrm{T} 2$ significantly differed from $\mathrm{T} 1$. The cholesterol values were significantly different $(\mathrm{P}<0.05)$, and tended to decrease progressively with increasing levels of COLM in the diets of the broilers. The alkaline phosphate (ALP) values were not significantly different $(\mathrm{P}>0.05)$, but however increased linearly with increasing levels of COLM in the diets of the broilers.

\section{Gut Microbial load}

The gut microbial load of broilers fed Chromolaena odorata leaf meal in their diets is presented in table 6 . The

Table 5: Blood chemistry of broilers fed Chromolaena odorata leaf meal in their diets.

\begin{tabular}{|l|c|c|c|c|c|}
\hline Parameter & T1 & T2 & T3 & T4 & SEM \\
\hline Total protein (g/dl) & $5.00^{\mathrm{b}}$ & $6.13^{\mathrm{a}}$ & $6.64^{\mathrm{a}}$ & $6.52^{\mathrm{a}}$ & 0.25 \\
\hline Albumin (g/dl) & $2.60^{\mathrm{b}}$ & $3.12^{\mathrm{ab}}$ & $3.41^{\mathrm{a}}$ & $3.22^{\mathrm{a}}$ & 0.11 \\
\hline Globulin (g/dl) & $2.40^{\mathrm{b}}$ & $3.01^{\mathrm{ab}}$ & $3.23^{\mathrm{a}}$ & $3.30^{\mathrm{a}}$ & 0.08 \\
\hline Urea (mmol/L) & 20.87 & 19.01 & 20.79 & 17.84 & 1.02 \\
\hline Creatinine (mmol/L) & $51.30^{\mathrm{a}}$ & $50.97^{\mathrm{b}}$ & $51.14^{\mathrm{ab}}$ & $51.06^{\mathrm{ab}}$ & 3.05 \\
\hline Cholesterol (mmol/L) & $95.18^{\mathrm{a}}$ & $90.12^{\mathrm{b}}$ & $82.47^{\mathrm{c}}$ & $68.76^{\mathrm{d}}$ & 3.17 \\
\hline ALP (U/L) & 66.47 & 72.64 & 73.32 & 77.37 & 2.02 \\
\hline AST (U/L) & 49.33 & 54.00 & 44.33 & 45.67 & 2.57 \\
\hline ALT (U/L) & 45.64 & 63.33 & 52.00 & 58.67 & 6.21 \\
\hline
\end{tabular}

${ }^{\mathrm{a}-\mathrm{d}}$ Means within the same row with different superscripts are significantly different $(\mathrm{P}<0.05)$

$\mathrm{ALP}=$ Alkaline phosphate, $\mathrm{AST}$-Aspartate amino transferase, $\mathrm{ALT}=$ amino transferase 
coliform was significantly $(\mathrm{P}<0.05)$ higher for the control group in comparison with the treatment groups for the crop. The coliform at the crop also showed $(\mathrm{P}>0.05)$ similarities between T2 and T3 while T3 and T4 were also similar while $\mathrm{T} 2$ and $\mathrm{T} 4$ significantly $(\mathrm{P}<0.05)$ different each other and $\mathrm{T} 1$. The Escherichia coli showed $(\mathrm{P}>0.05)$ similarities between $\mathrm{T} 1$ and $\mathrm{T} 2$, and between $\mathrm{T} 3$ and T4. However, T1 and T2 significantly $(\mathrm{P}<0.05)$ differed from $\mathrm{T} 3$ and $\mathrm{T} 4$. There was a linear decrease of coliform and E. coli with increasing levels of COLM in the diets from T1 to T4. There was a significant $(\mathrm{P}<0.05)$ increase of Lactobacillus in the crop and caecum with incremental levels of COLM. At the caecum, coliform showed no significant $(\mathrm{P}>0.05)$ difference between $\mathrm{T} 1$ and $\mathrm{T} 2$, but however differed significantly $(\mathrm{P}<0.05)$ delite from the other treatment groups. E. coli showed significant $(\mathrm{P}<0.05)$ for $\mathrm{T} 4$ and other treatments $(\mathrm{T} 1, \mathrm{~T} 2$ and $\mathrm{T} 3)$ which are statistically similar $(\mathrm{P}>0.05)$ to each other. T3 and T4 also showed no significant $(\mathrm{P}>0.05)$ for $\mathrm{E}$. coli in the caecum.

\section{DISCUSSION}

\section{Chemical compositions}

The proximate analysis of the COLM revealed a high dry matter value of $95.70 \%$ which was higher than $89.51 \%, 85.00 \%$ and $87.40 \%$ reported by Akinmutim and Akufo (2006), Bonsu et al. (2013) and Fasuyi et al. (2005) respectively. The crude protein content of $20.52 \%$ obtained in this present study for COLM is lower than the value of $22.80 \%$ reported by Bonsu et al. (2013) but higher than $15.27 \%$ and $16.20 \%$ reported by Ekenyem et al. (2009) and Igboh et al. (2009) respectively but however, comparable with $21.70 \%$ reported by Akinmutim and Akufo (2006) for the same leaf meal. The crude fibre (CF) content of $5.58 \%$ reported in this study is lower than the $11.49 \%$ and $20.10 \%, 13.72 \%$ and $11.67 \%$ reported by Bonsu et al. (2013), Ekenyem et al. (2009), Akinmutim and Akufo (2006) and Igboh et al. (2009) respectively. The relative low CF of COLM makes this leaf meal a potential feed stuff for monogastrics. The high ash content of COLM is an indication of high mineral profile of Chromolaena odorata leaves as attributed by Nwokolo (1987). However, the ash value of 9.29\% for COLM in this study is lower than $11.50 \%$ reported by Bonsu et al. (2013) and higher than 3.63 and 6.17 reported by Igboh et al. (2009) and Fasuyi et al. (2005) respectively, but favourably compared with $9.50 \%$ and $9.64 \%$ as reported by Ekenyem et al. (2009) and Akinmutim and Akufo (2006) respectively. Jiwuba et al. (2016b) attributed variation in the proximate compositions of leaf meals to the age of the plants, the stage of development when the leaves were harvested, location, season, soil type, the dry matter content and processing method used. The dry matter, crude protein and crude fibre contents of the test diets compared with the control diet and are in agreement nutrient requirements for broilers as stated by NRC (1994).

\section{Haematological studies}

All the haematological parameters evaluated, fell within the normal physiological range for apparently healthy broilers as reported by Simaraks et al. (2004) and Jiwuba et al. (2017) indicating that the diets were nutritionally adequate in providing a sound plane of nutrition for the birds. The non significance and within normal range of $\mathrm{Hb}, \mathrm{RBC}, \mathrm{MCHC}$, PCV and MCV gave a clear indication of absence anemia and feed toxicity. This further indicated that, all the birds had higher tendency to resist respiratory stress, due to the high level of $\mathrm{Hb}$, which is carried on the RBC, and thus the oxygen carrying pigment. Jiwuba et al. (2016c) earlier stated that $\mathrm{MCH}$ is used as an index of toxicity and its reduction in blood concentration usually suggests the presence of toxic factor like haemaglutinin which has adverse effect on blood formation. Perhaps the $\mathrm{MCH}$ values obtained for all the treatment groups in this study fell within the normal physiological range of 25.3-33.40 (Pg) as reported by Jiwuba et al. (2017) for apparently healthy broilers. The COLM promoted significantly and numerically higher $\mathrm{MCH}$ values when compared to the control, indicating that the processing methods employed in this study eliminated the anti nutritional factors to a tolerable level by the birds. Adedapo et al. (2016) however observed that Chromolaena odorata leaves have anti-anaemic properties. The anti-anaemic property maybe attributed to the high iron content of its chlorophyll. The white blood cell counts were significantly $(\mathrm{P}>0.05)$ affected by the treatment diets, with the animals on the test diets having a higher and improved values than the control group. The significant increase in WBC counts of birds fed the COLM suggests high immunity since the WBCs are known to be the key actors in immune responses as they form the first line of defense against invading microorganism. The observed significant increase in the WBC observed in this study is in agreement with the results of Ekenyem et al. (2009) who studied the effect of partial replacement of Chromolaena odorata for soybean on haematological and serum chemistry of laying birds. Adedapo et al. (2016) noted that Chromolaena odorata leaf extract have immunestimulating and prophylactic properties, which supports the result of this present study.

\section{Serum chemistry}

Serum biochemical studies are normally used for the diagnosis of organ diseases in farm animals. The values obtained in this study were within the normal range of serum protein 5.00-8.00 (g/dl) reported by Anon (1980) and 5.45$6.82 \mathrm{~g} / \mathrm{dl}$ reported by Ragab et al. (2012). Higher values of serum protein is an indication of enzyme hydrolysis of dietary proteins; demonstrating that the blood pool serves as a major source of amino acids needed for the synthesis of proteins. The albumin and globulin showed a significant difference with the test treatments having higher and better values than the control. The result of the present study however followed a similar trend with that of Ekenyem et al. (2009) for total protein, albumin and albumin for laying birds fed COLM. However, the values indicated nutritional adequacy of the test material in respect of protein, hence, high serum protein and albumin values are reflection of better quality and amount of protein in the diets (Jiwuba et al. 2016c). Globulin is an indicative of high immunity and good resistance to disease in 
Table 6: Gut microbial load of broilers fed Chromolaena odorata leaf meal in their diets

\begin{tabular}{|l|c|c|c|c|c|}
\hline Parameter & T1 & T2 & T3 & T4 & SEM \\
\hline Crop & & & & $4.66^{\mathrm{c}}$ & 3.05 \\
\hline Coliform $\left(10^{6}\right)$ & $7.67^{\mathrm{a}}$ & $6.33^{\mathrm{b}}$ & $5.00^{\mathrm{bc}}$ & $5.43^{\mathrm{b}}$ & 3.02 \\
\hline E. coli $\left(10^{6}\right)$ & $7.34^{\mathrm{a}}$ & $7.01^{\mathrm{a}}$ & $6.12^{\mathrm{b}}$ & $11.09^{\mathrm{a}}$ & 3.01 \\
\hline Lactobacillus $\left.10^{6}\right)$ & $7.10^{\mathrm{d}}$ & $8.53^{\mathrm{c}}$ & $9.81^{\mathrm{b}}$ & & $3.19^{\mathrm{c}}$ \\
\hline Caecum & & & & $4.62^{\mathrm{b}}$ & 3.94 \\
\hline Coliform $\left(10^{6}\right)$ & $8.11^{\mathrm{a}}$ & $8.02^{\mathrm{a}}$ & $6.71^{\mathrm{b}}$ & $12.33^{\mathrm{a}}$ & 3.64 \\
\hline E. coli $\left(10^{6}\right)$ & $6.34^{\mathrm{a}}$ & $6.07^{\mathrm{a}}$ & $5.31^{\mathrm{ab}}$ & $10.67^{\mathrm{b}}$ & \\
\hline Lactobacillus $\left(10^{6}\right)$ & $8.00^{\mathrm{d}}$ & $9.67^{\mathrm{c}}$ & & & 3.64 \\
\hline
\end{tabular}

experimental animals, the authors conclude. The increasing values of globulin observed in this study with increasing levels of COLM may be attributed to COLM due to its medicinal properties; a view corroborated by Akinmoladun et al. (2007), Vital and Windell (2009), Ekenyem et al. (2009) and Moses et al. (2010). Serum creatinine values ranged from $50.87-51.30 \mathrm{mmol} / \mathrm{L}$ in this present study. The values obtained were within the normal range of 44 to $135 \mathrm{mmol} / \mathrm{L}$. Higher values than normal may signify kidney malfunction and extent of muscle wastage. The within range of the serum creatinine of the broilers in this study suggested that the birds were not surviving at the expenses of body reserves. Hence there was no weight losses observed in the study. The present findings also reveal that the COLM caused a significant and consistent reduction in the levels of serum cholesterol. Ekenyem et al. (2009) observed non significant effect of COLM cholesterol concentration in laying birds. Ikewuchi and Ikewuchi (2011) reported that COLM significantly decreased serum cholesterol, cardiovascular complications, due to dyslipidemic conditions, hypertension and obesity. The findings of Uhegbu et al. (2016) reported reductions in total cholesterol, glucose and triacylglycerol when rats were fed Chromolaena odorata leaf extract. Adedapo et al. (2016) reported hypoglycemic and hypolipidemic properties of Chromolaena odorata leaf extract. This reduction in serum cholesterol level of broilers fed the COLM diet may suggest a general decline in lipid mobilization and maybe suggest that COLM diet were capable of reducing serum cholesterol, hence assisting in the reduction and deposition of cholesterol in the muscle; thus enhancing the production of lean meat.

\section{Gut microbial population}

The results showed that the broilers fed COLM in their diets had higher concentration of Lactobacillus compared to those fed control diet in the crop and caecum sections of the alimentary canal of the broilers. This suggests that the presence of COLM in the diets of broiler stimulated proliferation of Lactobacillus. Coliforms and E. coli were consistently higher in the birds fed the control diets than the birds fed the treatment diets in the crop and caecum. The overall results indicated that COLM diets stimulated the growth of Lactobacillus (beneficial bacteria). The stimulation of increased Lactobacillus populations by the COLM diets however resulted in the reduction of coliform and E. coli population in the crop and caecum respectively. This result thus suggested the efficacy of COLM in controlling pathogenic microorganisms and enhancing Lactobacillus population in the gut of broilers, thus an indicative of better nutrient availability for digestion and absorption. The inclusion of COLM in the diets of the experimental birds resulted in modulation of gut microflora towards proliferation of beneficial microflora. Jensen et al. (2003) further opined that the composition of the diet influences the species and number of bacteria in the gut.

\section{CONCLUSIONS}

The results of this study revealed that sun drying and subsequent milling as a processing methods, are the best for improving the nutritional value of COLM as no deleterious effects has been elicited on broiler chickens as evidenced by the within physiological range for all the haematological and serum biochemical indices studied. Similarly, the COLM diets stimulated Lactobacillus growth which in turn resulted to the reduction in coliform and E. coli populations. This establishes its potential usefulness in controlling pathogenic organisms, stimulation of erythropoiesis and immunity and influences metabolism in broilers.

From this study, it could be recommended that sun drying of Chromolaena odorata leaf meal and milling at 12\%\% level of inclusion can be used without any deleterious effect on the hematological and serum parameters and improved the population of beneficial gut microbe in broiler chicken. However, further researches are required by using other, processing techniques such as fermentation, biodegradation and higher inclusion levels.

\section{REFERENCES}

1. Adedapo AA, Ogunmiluyi IO, Adeoye AT, Ofuegbe SO, Emikpe BO. Evaluation of the medicinal potential of the methanol leaf extract of Chromolaena odorata in some laboratory animals. J. of Med. Plants Stud. 2016;4:29-37.

2. Akinmoladun AC, Ibukun EO, Dan-Ologe IA. Phytochemical constituents and antioxidant properties of extracts from the leaves of Chromolaena odorata. Sci. Res. Essay 2007;2:191-194.

3. Akinmutumi AH, Akufo A. The effect of graded levels of dietary inclusion of Siam weed Chlomolaena odorata leaf meal in grower rabbits diet in a Tropical environment. J. of 
Anim. Vet. Advan. 2006;5:700-711.

4. Anon. Guide to the care and use of experimental animals. Vol.1. Canadian Council on Animal Care. Ottawa, Ontario, Canada 1980;85-90.

5. AOAC. Association of Official Analytical Chemists: Official Methods of Analysis. 6th Edition. Washington DC, USA. 2000.

6. Apori SO, Long RJ, Castro FB, Ørskov ER. Chemical composition and nutritive value of leaves and stems of tropical weed Chromolaena odorata. Grass Forage Sci. 2000;55:7781.

7. Bonsu FRK, Kagya-Agyemang JK, Kwenin WKJ, Hope KN, Sekyere FO. Growth Performance, haematological indices and carcass characteristics of broilers fed diet containing different levels of Chromolaena odorata leaf meal. Egerton J. Sci. Technol. 2013;13:115-125.

8. Bryant MP, Burkey LA. Cultural methods and some characteristics of some of the more numerous groups of bacteria in the bovine rumen. J. of Dairy Sci. 1953;36:205-217.

9. Ekenyem BU, Obih TKO, Ohanaka AO, Nwajiuba CU. Effect of partial replacement of Chromolaena odorata for soybean on haematological and serum chemistry of laying birds. Int. J. of Tropical Agric. Food Syst. 2009;33:228232.

10. Fasuyi AO, Fajemilehin KSO, Aro SO. Nutritional potentials of Siam weed Chromolaena odorata) leaf meal SWLM) on laying hens: biochemical and haematological implications. Pakist. J. Nutrit. 2005;45:336-341.

11. Igboh MN, Ikewuchi CJ, Ikewuchi CC. Chemical Profile of Chromolaena odorata L. King and Robinson) Leaves. Pakist. J. Nutrit. 2009;8:521-524.

12. Ikewuchi JC, Ikewuchi CC. Anti-cholesterolemic Effect of Aqueous Extract of the Leaves of Chromolaena odorata L) King and Robinson Asteraceae. Potential for the Reduction of Cardiovascular Risk. The Pacific J. Sci. Technol. 2011;122:385-391.

13. Jensen BB, Hojberg O, Mikkelsen LL, Hedermann MS, Cannibe N. Enhancing intestinal function to treat and prevent intestinal disease. Proceedings of 9thInternational Symposium Dig. Physiol. In Pigs, Banff, AB. Canada 2003,1:103-119.

14. Jin LZ, Ho YW, Abdulla N, Jalaludin S. Growth performance, intestinal microbial populations and serum cholesterol of broilers fed diets containing Lactobacillus culture. Poultry Sci. 1998;77:1259-1265.

15. Jiwuba PC, Dauda E, Ezenwaka LC, Eluagu CJ. Replacement Value of Maize with Sweet Potato (Ipomoea batata) Root Meal on Growth Performance and Haematogical Characteristics of Broiler Starter Birds. Arch. Curr. Res. Int. 2016a;53:1-7.

16. Jiwuba PC, Ikwunze K, Ume SI, Nsidinanya NO. Performance, apparent nutrient digestibility and cost benefit of West African dwarf goats fed dietary levels of Moringa oleifera leaf meal. J. Advan. Biol. Biotech. 2016b;8:1-9.

17. Jiwuba PC, Ikwunze K, Dauda E, Ugwu DO. Haematological and serum biochemical indices of growing rabbits fed diets containing varying levels of Moringa oleifera leaf meal. Brit. Biotech. J. 2016c;15:1-7.

18. Jiwuba PC, Kuka TT, Kadurumba OE, Nwachukwu CO. Evaluation of haematological and serum biochemical characteristics of Annona muricata (Sour sop) leaf extract on broiler birds. International J. Res. Stud. Microb. and Biotech. 2017;3:6-11.

19. Moses SO, Akintayo O, Kamil OY, Labunmi L, Heather EV, Jessika AT, William N. Chemical composition and bioactivity of the essential oil of Chromolaena odorata from Nigeria. Records Nat. Prod. 2010;41:134-137.

20. NRC. Nutrient requirements for poultry. 9th Rev. Edn., National Academy Press, Washington, DC 1994.

21. Nwokolo E. Leaf meals of cassava Manihot esculenta) and Siam weed Eupatorium odoratum) as nutrient sources in poultry diets. Nutri. Report Int. 1987;36:819-826.

22. Ragab HI, Abdel Ati KA, Kijora C, Ibrahim S. Effect of Different Levels of the Processed Lablab purpureus Seeds on Laying Performance, Egg Quality and Serum Parameters. Int. J. of Poult. Sci. 2012;11:131-137.

23. Sajise JH, Madrid JA, Kohler DD. Biology of Chromolaena odorata. Philippine J. Weed Sci. 1974;1:83-87.

24. Simaraks S, Chinrasri O, Aengwanich W. Hematological, electrolyte and serum biochemical values of the Thai indigenous chickens (Gallus domesticus) in northeastern, Thailand. Songklanakarin J. Sci. Technol. 2004;26:426430.

25. Uhegbu FO, Chibuzo CI, Onwuegbuchulam H. Lipid lowering, hypoglycemic and antioxidant activities of Chromolaena odorata L) and Ageratum conyzoides L) ethanolic leaf extracts in albino rats. J. Med. Plants Stud. 2016;42:155-159.

26. Vital PG, Windell LR. Antimicrobial activity and cytotoxicity of Chromolaena odorata L. f.) King and Robinson and Uncaria perrottetii A. Rich) Merr. Extracts. J. Med. Plants Res. 2009;37:511-518. 


\section{Krvna slika in mikroflora črevesja brojlerskih piščancev krmljenih z listno moko (Chromolaena odorata)}

\section{IZVLEČEK}

Proučevani so bili odzivi 96-dnevnih piščancev, ki so bili 49 dni krmljeni z vključevanjem listne moke Chromolaena odorata (COLM) v obrok na profilu njihove krvi in mikroflore črevesja. Piščanci so bili naključno razdeljeni v štiri naključno oblikovane poskusne skupine in tri ponovitve. Piščanci so bili krmljeni s štirimi eksperimentalnimi dietami, s 0\%, 2\%, 4\% in 6\% COLM za prvo fazo pitanja - štarter krmo in s $0 \%, 4 \%, 8 \%$ in 12\% COLM v drugi fazi - finišer krmo. Skupine so bile označene kot za T1, $\mathrm{T} 2$, T3 in T4.

Vsi hematološki parametri so bili statistično neznačilni $(\mathrm{P}>0,05)$ med skupinami, razen pri MCH in WBC, ki so bili značilno $(\mathrm{P}<0,05)$ višji v testiranih skupinah $\mathrm{v}$ primerjavi s kontrolo. Rezultati serumske analize so pokazali značilne razlike $(\mathrm{P}<0,05)$ za testirane skupine za lastnosti kot so skupne beljakovine, albumin, kreatin in holesterol v primerjavi s kontrolno skupino. Holesterol je bil značilno $(\mathrm{P}<0,05)$ manjši z naraščajočimi odstotki COLM v krmi piščancev. Rezultati analiz so pokazali, da so vsebnosti coliformnih mikroorganizmov in E. coli značilno višje $(\mathrm{P}<0,05)$ pri piščancih iz kontrole T1 v primerjavi s T2, T3 in T4 skupino. Ugotovljeno je bilo, da je COLM spodbudno deluje na hematokrit in imunski status, na hipoglikemično sposobnost, zavira rast črevesnih patogenih mikroorganizmov in povečala rast koristnih mikroorganizmov v črevesju pitovnih piščancev.

Ključne besede: pitovni piščanci, COLM, listna moka, zdravje črevesja, krvna slika, zdravilna rastlina 